\title{
Mortgage interest deductibility and homeownership in the Netherlands
}

\author{
Jan Rouwendal
}

Received: 16 August 2007/ Accepted: 16 August 2007/Published online: 9 September 2007

(C) Springer Science+Business Media B.V. 2007

\begin{abstract}
This paper considers the growing amount of mortgage interest paid in the Netherlands against the background of its full fiscal deductibility, increasing homeownership rates, innovation in the mortgage market, and changes in the Dutch income tax system. Its main conclusion is that arguments in favor of fiscal deductibility are weak. Since the deductibility puts pressure on the income tax base, it is likely that sooner or later the facility must be limited or abandoned.
\end{abstract}

Keywords Housing policy · Mortgage interest deductibility $\cdot$ Homeownership

\section{Introduction}

The Netherlands is one of the few countries in the world - the USA being the primary other example-where interest paid on mortgage loans is fully deductible from taxable income. Some of the surrounding countries have never had this tax facility, while others have abolished it or put substantial limitations on the fiscal deductibility. The continuation of mortgage interest deductibility is a hot issue in the national policy debate. This is somewhat surprising — at least at first sight—-since it dates back to the beginning of the 20th century and has essentially remained unchanged. Moreover, marginal tax rates have decreased during the past 25 years and nominal mortgage interest rates are much lower now than they were in the 1980 s.

In this paper we take a closer look at the treatment of owner-occupiers by the Dutch income tax system. We start with a brief discussion of mortgage interest deductibility and the associated debate. Then we take a closer look at the arguments in favor of this measure and conclude that they are weak. We document the increasing use made of mortgage interest deductibility in Sect. 5 and proceed with a discussion of the role of innovations on the mortgage market and the incentives provided by the current Dutch tax system. In Sect. 8,

\section{J. Rouwendal ( $\bowtie)$}

Department of Spatial Economics, VU University and Netspar, De Boelelaan 1105, 1081 HV,

Amsterdam, The Netherlands

e-mail: jrouwendal@feweb.vu.nl 
the paper concludes with a discussion of some possible developments and scenarios for the future. Throughout the paper we focus on the Dutch situation. A discussion of the international context has been provided in Boelhouwer et al. (2004).

\section{Mortgage interest deductibility in the Netherlands}

The origins of the deductibility of mortgage interest paid from taxable income are to be found in the Dutch income tax system as it was constructed in the first quarter of the 20th century. One of the principles of that system was that costs incurred to realize income are exempt from income taxation. Mortgage interest paid was regarded, as a cost necessary to realize income-in kind-from the home one owns. The deductibility of mortgage interest paid is therefore complemented by the taxation of the benefit an owner derives from his house. In accordance with this principle, Dutch owner-occupiers have to add the rental value of their house to taxable income.

The current practice is as follows. A homeowner with a mortgage loan can deduct the interest paid on the outstanding amount of money from his taxable income. The net interest payment of the homeowner is the difference between gross interest payments and the tax payment that is avoided through the deductibility. The tax saving is equal to the product of the marginal tax rate and the gross interest payments. For most Dutch taxpayers the marginal rate equals $42 \%$ or $52 \%$, implying that net mortgage interest payments are substantially lower than gross payments. ${ }^{1}$

The imputed rent is proportional to the value of the house as estimated for the purposes of the real estate tax. Such estimates are made regularly for every house in the Netherlands and are in general lower than the market price. $^{2}$ Moreover, the imputed rent is set as equal to only $0.6 \%$ of this estimate.

The total effect of homeownership on the amount of income tax paid is equal to the difference between the tax savings that result from the deductibility of paid mortgage interest and the tax that has to be paid over the imputed rent. Given the above figures, it will come as no surprise that for the great majority of the household population, homeownership decreases the total amount of income tax that has to be paid. Only for outright owners and those with a small mortgage can the net effect of the two tax measures be an increase in the total amount of income tax to be paid. However, a recent change in the tax system determines that in such cases the tax increase that would result from homeownership does not have to be paid. This excludes the possibility that homeownership will result in higher income tax payments.

The fact that the mortgage interest deductibility fits into a basic principle of the income tax system can be regarded as a justification of its existence. Nevertheless, the description given above immediately reveals an important weakness in any defense of this tax facility based on this logic. Subtraction of the costs of homeownership from taxable income is justified because the associated benefits are taxed and the system only intends to tax the net benefits. However, for the purposes of the tax system the benefits are determined in such a way that they can never exceed the costs, which seems illogical. It is clear, therefore, that

\footnotetext{
${ }^{1}$ See Haffner (2002) for a more extensive analysis of the treatment of owner-occupied housing in the Dutch income tax system.

${ }^{2}$ See, for instance, de Vries et al. (2006) for an analysis of the relationship between these estimated values and market prices.
} 
in the present circumstance mortgage interest deductibility cannot serve the purpose for which it was originally introduced and must be defended by other motives. This complicates the position of the supporters of this tax facility.

\section{Reasons behind the current debate}

The main reason for the current debate on mortgage interest deductibility in the Netherlands is the large and ever growing amount of paid interest that is deducted from income tax. The tax savings for the homeowners are a tax expenditure on the part of the government. For the year 2006 the CPB expects a decrease in total revenues of income taxation due to mortgage interest deductibility of 11.75 billion euros, while the taxation of imputed rent is expected to result in 2 billion euros of revenues, implying a net tax expenditure of 9.75 billion euros. ${ }^{3}$

The tax expenditure associated with mortgage interest deductibility increased rapidly in recent years. The lost income tax revenues from mortgage interest deductibility were less than 6 billion euros in 1995 and have almost doubled in 11 years. In the same period the revenues generated by taxation of the imputed rent remained almost constant at 2 billion euros. Since 1995 the mortgage interest rate decreased substantially, suggesting a decrease in mortgage interest payments, while house prices more than doubled, suggesting an increase in imputed rents. Even though it should, of course, be realized that these two effects counteract each other (higher house prices may lead to larger mortgage loans, which increase mortgage interest payments), the increase in the amount of mortgage interest paid is surprisingly large. The absence of an increase in the revenues from taxing imputed rents was caused by changes in the system of determining this variable, which effectively implied a lower value. The substantial increase in the net tax expenditure involved is an important reason for concern about the income tax base.

A second reason for the debate is that the tax savings are especially large for households with high incomes. These households are often homeowners and they usually live in large houses. The decisive fact is, of course, that they also have larger mortgage loans than households with lower incomes. Table 1 provides information about the relationship between homeownership and the income distribution. The second column of this table gives average net monthly income per decile. It confirms the well-known regularity that homeownership increases with income (after the second decile). The monthly amount of mortgage interest paid is more or less constant between the second and fifth decile but increases strongly in the upper half of the income distribution. The last column of the table shows, somewhat surprisingly, that imputed monthly rent decreases slightly with income until the fifth decile and increases modestly until the last decile. Imputed rent is computed as $0.6 \%$ of the value of the house as estimated for the real estate tax, divided by 12 . Since this estimate is also used in actual income taxation, it is probable that this feature of the data reflects the reality of Dutch income taxation.

The figures in Table 1 show that in all deciles the average amount of mortgage interest paid is much larger than the average imputed rent. The difference between the two exceeds 250 euros per month in the lower half of the income distribution and is as large as 600 euros per month in the tenth decile, where almost $90 \%$ of the households are homeowners. It is clear that the households with the highest incomes realize the largest deductions from

3 See Van Ewijk et al. (2006). 
Table 1 Homeownership and income distribution

\begin{tabular}{lllll}
\hline Decile & $\begin{array}{l}\text { Av. net monthly } \\
\text { income (euros) }\end{array}$ & $\%$ homeowner & $\begin{array}{l}\text { Monthly mortgage } \\
\text { interest paid (euros) }\end{array}$ & $\begin{array}{l}\text { Imputed monthly } \\
\text { rent (euros) }\end{array}$ \\
\hline 1 & 405 & 49 & 456 & 89 \\
2 & 876 & 28 & 354 & 79 \\
3 & 1,163 & 32 & 367 & 77 \\
4 & 1,439 & 38 & 349 & 70 \\
5 & 1,733 & 46 & 360 & 71 \\
6 & 2,061 & 57 & 388 & 73 \\
7 & 2,439 & 66 & 429 & 74 \\
8 & 2,879 & 76 & 482 & 77 \\
9 & 3,470 & 83 & 546 & 83 \\
10 & 5,497 & 88 & 709 & 105 \\
\hline
\end{tabular}

Source: WBO 2002. The last two columns refer to homeowners only

their taxable income because of their homeownership. Note, moreover, that these incomes have the highest marginal tax rates and therefore realize the largest tax savings. ${ }^{4}$

The deterioration of the income tax base and the relatively large share of the associated benefits flowing to high-income households are the main reasons for concern about mortgage interest deductibility. Some other considerations add to this concern. Since surrounding countries have abandoned or limited this facility, the Netherlands is in a somewhat exceptional position in the European Union. It is sometimes also argued that mortgage interest deductibility is one of the reasons behind the currently high house prices in the Netherlands. However, it is unclear how a tax facility that has been present for almost a century could be the reason for an increase in the price of housing in the last decade..$^{5}$

Abolishing mortgage interest deductibility could have major consequences for household incomes. The figures in Table 1 make it clear that changes in net household income of 100 euros per month or more will be no exception. Partial abandonment by introducing substantial limitations on this facility can also have important effects. It is mainly for this reason that proposals to change the mortgage interest deductibility have potentially large electoral consequences. Political parties-especially the largest ones-are strongly inclined to declare that they do not intend to change it, or at least that they would be very careful about introducing such changes. However, the two main arguments presented above are strong enough to keep the discussion alive. The general expectation is that sooner or later mortgage interest deductibility will be limited or perhaps abandoned altogether.

\section{Arguments in favor of mortgage interest deductibility}

Section 2 noted that mortgage interest deductibility was-historically-the consequence of a basic principle of taxation, implying that costs incurred to realize income can be

\footnotetext{
${ }^{4}$ It is also clear from Table 1 that the ratio of mortgage payments to income decreases with income.

5 It may be remarked that the product innovations in the mortgage market, which exploit the benefits of mortgage interest deductibility to a larger extent, have contributed to the increase in housing demand over the last 25 years. In combination with inelastic housing supply, this has probably contributed to the increase in Dutch house prices. Note, however, that in this interpretation mortgage interest deductibility is only one of the relevant elements of the explanation.
} 
subtracted from taxable income. The associated fiscal treatment of owner-occupation can be motivated in various ways. One possibility is to compare owner-occupation with renting. In order to treat renting and owner-occupation similarly, one should distinguish two aspects of homeownership: on the one hand, the homeowner can be regarded as renting a house; on the other hand, he is the owner who lets the same house. As an owner he earns the rent from the house, which gives him income. Also as an owner he has costs that can be subtracted from this income before it is taxed. Equal treatment of the rental and owneroccupied sector of the housing market therefore requires the taxation of imputed rent in combination with mortgage interest deductibility.

Related to this reasoning is the argument that fiscal deductibility is necessary to ensure that debt and equity financing of houses are treated symmetrically. This point has recently been raised by Hendershott and Pryce (2006), who refer to Woodward and Weicher (1989) for a more elaborate defense. Briefly, the argument is that the opportunity costs of debt financing are the net returns on alternative uses of equity. If capital income is taxed in the same way as other income, the net returns are equal to the gross returns multiplied by one minus the marginal tax rate. If the gross returns are equal to the mortgage interest rate (possibly after a correction for exposure to risk), a homeowner should be indifferent to the distinction between debt financing and equity financing if there is fiscal deductibility of paid mortgage interest. In the absence of such deductibility, there would be a bias against debt financing of housing.

The first argument is perfectly valid, but it suffers from the fact that the proper taxation of the owner-occupier as a homeowner requires knowledge of the rent. Elementary economic logic suggests that households will only buy a house when the benefits are greater than the cost. A correct determination of the benefits in the form of imputed rents should therefore be expected to result — under normal circumstances - in a value for the imputed rent that is at least as high as the mortgage interest payments. The recipe for the large tax expenditure associated with the current fiscal treatment of owner-occupied housing suggested by this reasoning is therefore to increase the imputed rent substantially.

For various reasons, this option is extremely unrealistic. Naturally, the taxation of the imaginary rent of a house occupied by its owner is very unpopular among homeowners, who will dispute the imputed value whenever they can. One way to minimize such disputes, and the associated political pressure from homeowners, is to take care that the estimates are conservative. Moreover, since homeownership is generally regarded as the preferred tenure type, many politicians are inclined to conclude that taxing imputed rent comes close to taxing homeownership, which is undesirable. This reasoning completely overlooks the motivation for introducing the combination of taxation of imputed rent and mortgage interest deductibility, thereby effectively undermining the first argument for mortgage interest deductibility.

It may be added that other changes in the tax system make mortgage interest deductibility appear less self-evident now than it was originally. The principle by which the taxpayer's costs are exempt from taxation was originally taken to imply that all interest received by the taxpayer should be taxed, while all interest paid by the taxpayer would be exempt. ${ }^{6}$ However, this rule has gradually been abandoned by the government. The deductibility of interest paid on consumer credit that did not have housing as collateral was abandoned first. This allowed homeowners to increase the size of the mortgage loan in

\footnotetext{
${ }^{6}$ It should, of course, be noted that this reflects a very broad interpretation of the underlying rule, especially since there was no serious attempt to tax the benefits that justified the interpretation of interest payments as costs.
} 
order to finance the purchase of durable consumption goods at much lower effective interest rate than would otherwise be possible. The next step was therefore to restrict the deductibility of mortgage interest paid to loans used for buying or improving a house. Recently, mortgage interest deductibility was further restricted by excluding mortgage loans on second houses. As a result of this series of restrictions, mortgage interest deductibility for the main dwelling of a household came to be regarded naturally as an exception rather than as an application of a basic rule.

The second argument has also become invalid. The most recent tax reform in the Netherlands, dating back to 2001, introduced a separation between the taxation of income from capital (excluding the house) and that from other sources (notably from labor). The two types of income are treated according to different regimes ('boxes'). Capital income is determined on the basis of imputed returns on capital of $4 \%$ and is taxed at a $30 \%$ rate. Imputed rent and mortgage interest paid are dealt with in the box for labor income, and the associated marginal rates are always higher than 30\%. This means that in the current Dutch income tax system, the second argument cannot be used to defend the practice of mortgage interest deductibility as it stands. It can, of course, be used to motivate the transfer of the owner-occupied house to the box for capital income, but this would imply a substantial change in the fiscal treatment of owner-occupied housing.

That leaves the proponents of mortgage interest deductibility with the argument that homeownership should be subsidized. The justification for such a subsidy must be the external effects associated with homeownership. For instance, homeowners could be regarded as acting more responsibly than other citizens because they have their property to take care of. It is in general difficult to evaluate such arguments. Glaeser and Shapiro (2002) provide an extensive analysis for the United States, which concludes that the argument has some merit, but that:

the home mortgage interest deduction is really not a pro-ownership policy in any meaningful sense. It subsidizes housing consumption, but its impact on the homeownership rate appears to be minimal. (Glaeser and Shapiro 2002, p. 47)

Especially the fact the mortgage interest deductibility is targeted at the wealthy, who have higher housing consumption and higher marginal tax rates, makes it difficult to defend it as a policy instrument that can be used to promote homeownership.

Note also that the measure was originally not intended to promote homeownership. The previous sections made it clear that the mortgage interest deductibility was present for a long time before it came to be defended as a means to promote homeownership. Moreover, the share of owner-occupiers in the Dutch population has increased substantially over time, which suggests a decreasing need for further promotion of homeownership. ${ }^{7}$

Subsidies on the construction of rental housing formerly provided an argument for granting similar subsidies to the owner-occupied sector, but they were abandoned in the Netherlands in the 1990s. ${ }^{8}$ Also the tax expenditure involved in the housing allowance (which reduces tax payments for low-income households with a high rent-to-income ratio) is much smaller than that involved in mortgage interest deductibility.

\footnotetext{
7 The share of owner-occupiers among Dutch households was 55\% in 2003, which is still relatively low. Among 25 European countries only four had a lower share of owner-occupied housing than the Netherlands in 2003 (see VROM 2006).

${ }^{8}$ It may be argued that most of the existing rental housing stock was constructed with a subsidy. This was reflected in the original rent for these houses. However, since the 1990s real rents have increased gradually and it is not obvious that they still reflect the formerly existing subsidies for rental housing construction.
} 
Fig. 1 The development of homeownership in the Netherlands. Source: Housing Needs Surveys, various years

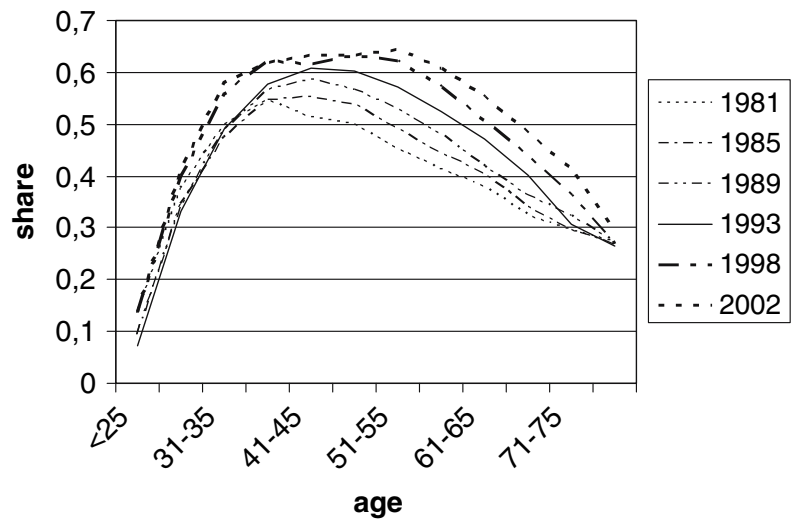

Summarizing, it may be said that a number of developments in the tax system and in Dutch housing policy have undermined most of the arguments in favor of mortgage interest deductibility in its present form. At the same time, it is obvious that abolition of the measure is potentially very harmful to owner-occupiers receiving large benefits from this rule. ${ }^{9}$ In the sections that follow we take a closer look at the reasons behind the large and still growing popularity of the measure.

\section{What causes the increase in paid mortgage interest?}

In the present and next sections we investigate the backgrounds of the - at first sightparadoxical observation that the tax expenditure associated with mortgage interest deductibility increased substantially in a decade when the marginal tax rate was lowered and mortgage interest rates were declining. In this section we first consider the development of homeownership, then the share of homeowners with a mortgage loan, and finally the average amount of mortgage interest paid by these homeowners. In the next section we draw attention to the role of product innovation on the mortgage market.

Figure 1 documents the increase in homeownership rates on the basis of a series of Housing Needs Surveys. It shows that in the early 1980s about $50 \%$ of the middle aged were homeowners, whereas most of the younger and older households were renters. In the years that followed, homeownership rates among the middle aged increased. Moreover, households that became homeowners remained so when ageing. In 2002, more than $60 \%$ of the households between 30 and 60 years of age were owner-occupiers, and the figure suggests that homeownership rates among the elderly will also increase to that level in the near future.

An increasing share of homeowners leads to increased mortgage interest payments unless the share of homeowners with a mortgage falls. Figure 2 shows that in fact the share of homeowners with a mortgage loan has increased in all age groups, but especially among the elderly. It shows a gradual decrease in the share of outright owners among all age groups, but in particular among the elderly households.

\footnotetext{
9 Koning et al. (2006) provide an analysis of the effects of restricting or abolishing mortgage interest deductibility on the Dutch housing market.
} 
Fig. 2 The development of the share of homeowners with a mortgage in the Netherlands. Source: Housing Needs Surveys, various years
Fig. 3 The development of average monthly mortgage payments. Source: Housing Needs Surveys, various years
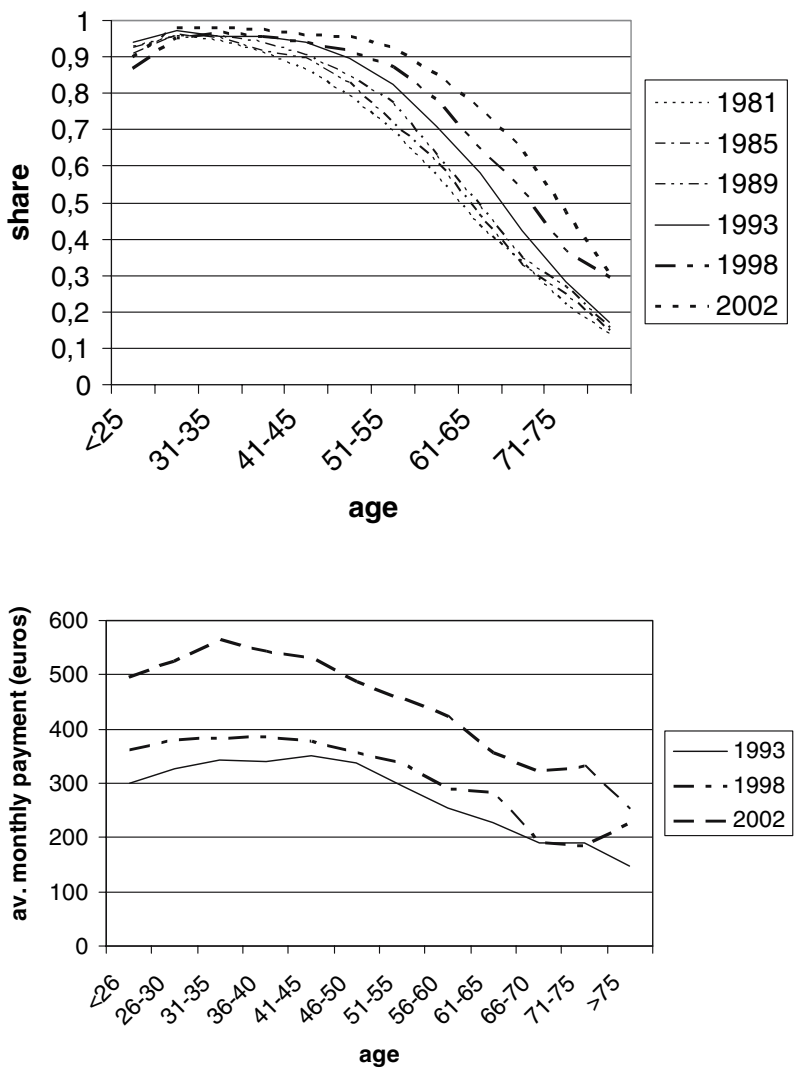

Figure 3 shows the average monthly mortgage interest payments of households with a mortgage in 1993, 1998, and 2002. ${ }^{10}$ Especially in the last period mortgage payments increased considerably for all age classes. Note that the mortgage interest rate was gradually decreasing throughout the 1990s. Figure 3 therefore suggests that the average amount of outstanding debt per household has increased substantially.

The three figures tell a clear story: homeownership rates have increased; the share of homeowners with at least one mortgage has increased; and the outstanding amount of mortgage debt per household has increased. All three factors contributed to the growing amount of outstanding mortgage debt. One may, of course, ask the next question: what explains these developments? A complete answer is outside the scope of this paper, but we will discuss some relevant factors.

We should certainly mention the combination of high house prices and rising incomes. House prices have increased considerably over the last 25 years, especially during the $90 \mathrm{~s}$. This development coincided with a decreasing trend in the mortgage interest rates, and it has been documented repeatedly that affordability of housing did not change substantially in the course of this period. To measure affordability, a recent study (Renes et al. 2006) considers the situation in which the average house is financed completely by a mortgage

\footnotetext{
10 The Housing Needs Surveys of 1981, 1985, and 1989 suggest that average mortgage payments were so much lower during these earlier years that the possibility that these data are not comparable with those of later years comes naturally to mind. This issue has to be investigated further.
} 
loan. The ratio between the implied interest payments and the income of the average household is then taken as an indicator of affordability. If household income remains unchanged, a constant affordability index implies constant interest payments. If household incomes increase and the interest rate decreases, affordability remains constant when the amount of outstanding debt per household increases sufficiently to keep the ratio of mortgage interest payments to income unchanged. This is what happened in the 1990s. Economic growth was strong during these years, and an increasing share of two-earner households caused average household income to grow even faster than per capita income. The substantial increase in house prices is consistent with the low value of the price elasticity of housing supply found by Vermeulen and Rouwendal (2007).

This suggests the following explanation of the increase in the total amount of outstanding mortgage debt. Economic growth and decreasing interest rates fueled the demand for housing. Since supply is inelastic, this led to an increase in house prices. The higher house prices could only be paid by taking larger mortgage loans, and this was facilitated by the lower interest rates. A substantial part of the developments documented earlier in this section can be explained in this way. But the increasing share of elderly owner-occupiers with a mortgage loan cannot be explained by this story. Moreover, the percentage increase in average monthly mortgage payments by households with at least one mortgage loan shown in Figure 3 seems much larger than the percentage increase in average household income over the same period. It would therefore be necessary to add other factors to arrive at a more complete explanation.

An important development that has not yet been discussed is the increasing popularity of a second mortgage, as documented, for instance, in Van Rooij and Stokman (2000). The rapidly increasing house prices in the 1990s created a large amount of illiquid wealth for existing homeowners, and taking a second mortgage loan is a possibility to release some of it. From the Housing Needs Surveys, it appears that the share of homeowners with two or more mortgages increased from 5\% in 1993 to $10 \%$ in 1998 and to $13 \%$ in 2002. The increasing popularity of liquefying some of the housing equity by taking an (additional) mortgage loan induced the national government to limit fiscal deductibility of the interest paid on these loans to cases in which the loan was used to finance improvements of the home.

Another relevant development—namely, new types of mortgage—will be discussed in the next section.

\section{Product innovation in the mortgage market}

The mortgage market in the Netherlands is well developed, and over the years a number of new mortgage types have been introduced into the market. It will be argued in this section that this development has contributed significantly to the increased amount of mortgage interest that is deducted from taxable income.

Until the 1980s the linear (or serial) mortgage loan was the most popular type. In every period the homeowner repays a fixed share of the original loan. The outstanding amount of the loan decreases linearly over time and so do interest payments and the associated tax savings. In the1980s the annuity mortgage became the most popular type. For this mortgage type the repayment and the (gross) interest payments remain constant over time. Repayment of the annuity mortgage loan proceeds at a slower rate than with the serial mortgage loan. Over the whole term of the loan, more interest is paid and deducted from taxable income. 


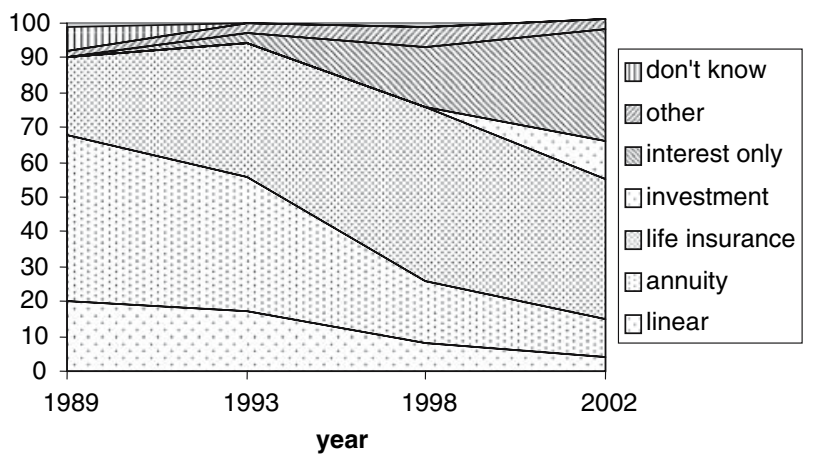

Fig. 4 Market shares of various mortgage types. Source: Housing Needs Surveys, various years. Note: the market shares refer to homeowners with one mortgage loan

Perhaps the most important innovation on the mortgage market that occurred over the last two decades in the Netherlands was the life insurance mortgage loan. It combines a life insurance policy and a mortgage loan into an endowment type of mortgage loan. The loan is not repaid until the end of its term. To make sure that enough money is available to repay the loan at that time, the homeowner saves on a different account. This combination becomes especially attractive if saving takes the form of a premium for a life insurance policy, because the interest received over the premium paid remains untaxed. The conventional arrangement is that the life insurance pays out at the end of the term of the mortgage loan, unless the homeowner dies before that time. In that case the loan will be redeemed earlier (it is really a life insurance).

By also making use of the tax exemption of interest received on a life insurance account, the life insurance mortgage loan provides the homeowner with a real advantage over the serial or annuity mortgage loan. It should be noted that with this type of mortgage loan, mortgage interest has to be paid over the whole duration of the loan (there is no repayment until the end of its term), which means that maximum use is made of the mortgage interest deductibility. The increasing popularity of this type of mortgage loan thus contributes to the explanation of the increasing amount of total mortgage interest paid by the average household. ${ }^{11}$

More recently other mortgage types have been introduced that allow the homeowner more freedom for repayment. Sometimes repayment has to be made from the returns on investments in stocks or other securities, which are expected-by some-to give higher returns than savings accounts (or paying the premium for the life insurance). The interestonly mortgage has also rapidly gained a substantial market share, as is documented in Fig. 4. The figure shows that the linear and annuity mortgages covered two-thirds of the market in 1989, while their total market share was less than $20 \%$ in 2002 . A common characteristic of the newer mortgage types is that the loan is not repaid until the end of its term (which is left undefined with an interest-only mortgage). For this reason they tend to increase the average amount of mortgage interest paid and deducted from taxable income by the homeowner.

\footnotetext{
${ }^{11}$ It is a somewhat paradoxical fact that the special tax facilities for life insurances used in the life insurance or savings mortgage were available long before this type of mortgage loan was introduced. Anyone who wished to use it could do so. However, few took this opportunity until it was combined with a mortgage loan and offered as a package. Then it gained enormous popularity.
} 


\section{Incentives offered by the current Dutch income tax system}

A final aspect of the mortgage interest deductibility consists of the incentives for choice of a mortgage type that the current Dutch tax system offers. To analyze them, we consider a household that wants to buy a house with price $P$ and have a sufficient amount of liquid wealth available to finance it completely with its own money. We compare this possibility of being an outright owner immediately with that of financing the house completely with a mortgage loan. To focus on the consequences of these two alternative financing opportunities, we abstract from maintenance costs and all other aspects of housing costs that are independent of the way the house is financed.

If the household chooses to use its own wealth to finance the house, it should realize that it will not receive the returns that could otherwise have been realized. This opportunity cost is equal to the product of the net returns $\rho^{\text {net }}$ of the most preferred alternative investment opportunity and the price of the house. Moreover, the household has to pay income tax over the imputed rent of the house. Imputed rent equals $\lambda P$, with $\lambda$ the share of the house price used in the tax rule. The total annual net costs are therefore equal to $\left(\rho^{\text {net }}+\tau \lambda\right) P$.

Alternatively, the household could use a mortgage loan to finance the house completely. The mortgage interest rate is $r$. Since paid mortgage interest is deductible from taxable income, the total cost of housing is in this case equal to $((1-\tau) r+\tau \lambda) P$. Clearly, the mortgage will be preferred if $\rho^{\text {net }}<(1-\tau) r$, where $\tau$ denotes the marginal tax rate. Financing the house with a mortgage loan is therefore attractive if the after-tax return on the alternative use of household wealth is higher than the net mortgage interest rate.

Before the tax reform of 2001, returns on capital and earnings were taxed identically. This means that $\rho^{n e t}=(1-\tau) \rho$, where $\rho$ is the gross rate of return on capital. In that situation the gross return had to exceed the interest rate to make financing the house with a mortgage loan attractive. If the most preferred alternative use of capital has a gross return that is lower than the mortgage interest rate, mortgage financing is not attractive. Hence households who prefer to put their wealth into savings accounts or government bonds will tend to be outright owners, since these low-risk assets typically have a rate of return that is lower than the mortgage interest rate. However, if a household has stocks as its most preferred alternative, the expected gross rate of return on capital may well have been higher than the mortgage interest rate. For such households, debt financing of the house may have been preferred even under the older tax regime. ${ }^{12}$

The tax reform of 2001 introduced a distinction between the taxation of earnings and that of the returns on capital. The latter are taxed on the basis of a hypothetical annual return of $4 \%$ at a marginal rate of $30 \%$. This is lower than the marginal tax on earnings in all tax brackets. If the return on capital is equal to the mortgage interest rate, and even when it is slightly lower, a household would therefore prefer to finance the house completely with a mortgage loan. This means that the current Dutch tax system provides an incentive for households to maximize mortgage financing.

This can be clarified by means of an example. If the price $P$ is equal to 250,000 euros and the interest rate equals $5 \%$, annual mortgage interest payments amount to 12,500 euros. With a marginal tax rate of $50 \%$ and $\lambda$ equal to 0.006 , the tax to be paid on imputed rent equals 750 euros. Taking into account mortgage interest deductibility, we find that housing costs are equal to 7,000 euros. If the gross return on the preferred alternative use of the household's capital is $4 \%$ and is taxed at the same marginal rate of $50 \%$, it is clearly

\footnotetext{
12 Note that the life insurance/savings mortgage avoids the tax on the alternative use of capital, which is the main explanation for its popularity, as discussed in the previous section.
} 
beneficial to accumulate equity in the house. The opportunity cost associated with being an outright owner is equal to $5,000+750=5,750$ euros. However, if the marginal tax rate on returns to capital is only $30 \%$, the opportunity cost of being an outright owner equals (1$0.3)^{*} 10,000+750=7,750$ and this exceeds the cost of mortgage financing. It is clear, therefore, that even with a modest return on capital, it is unattractive to repay the mortgage.

It should therefore be expected that under the new tax system the average amount of mortgage interest paid by Dutch households will continue to increase. The consequence will be a further deterioration of the income tax base, which should be expected to fuel the debate about mortgage interest deductibility and its targeting of higher incomes. In the absence of appropriate arguments in favor of the measure, it must be expected that it will ultimately be limited and perhaps in the long run abolished, as happened earlier in other European countries.

\section{Young and elderly homeowners}

In the public debate, the high housing prices in the Netherlands are often connected with mortgage interest deductibility. The main argument is that the subsidy implied by this measure would drive up the price of houses. However, this can only happen if the elasticity of housing supply is low. If this is the case, the high house prices should be attributed principally to this feature of the Dutch housing market. It has been observed above that housing affordability has in fact not changed in the Netherlands over the last 20 years. Increasing incomes and lower interest rates have compensated for the effect of higher house prices on the housing costs of owner-occupiers. The fact that homeownership rates among younger households have increased since the mid-1990s is in line with this observation.

Much larger changes in homeownership rates are to be found among elderly households. Figure 1 shows that this rate increased by $20 \%$ for those aged between 56 and 60 . This development is likely to continue over the coming years. It is also clear from Figs. 2 and 3 that a much larger share of the elderly homeowners now have a mortgage, and that they pay more interest if that is the case. Since interest rates have been decreasing, this reflects larger mortgage loans taken by elderly households.

Even though house prices change over time in an unpredictable way, homeownership should not necessarily be regarded as risky. Investments in one's own home give a certain return in kind. If house prices are strongly correlated over space (as is likely to be the case), house prices matter only for households intending to trade up or down. Moreover, the increase in outstanding mortgage debt that has been documented in this paper does not necessarily indicate a more vulnerable financial position of these households. House prices increased so much in the 1990s that it is possible to have both a larger mortgage and more equity while owning the same home as in 1980 . We noted in the previous section that some of the larger mortgages currently observed may be the result of the incentives provided by the current tax system, which tend to make repayment unattractive. It is therefore quite possible, and to some extent probable, that the larger mortgages are combined with investments in securities like bonds or stocks.

There is, nevertheless, some reason for concern about this development. Mortgage loans themselves have become more risky, since variable interest rates are more popular nowadays than they were in the past. Moreover, if mortgage loans are balanced by investments in other securities, the net risk of the household is higher than when this wealth was used to 
pay back the mortgage. It appears, therefore, that mortgage interest deductibility forms a strong incentive for households to bear more financial risks.

\section{Conclusion}

In the previous sections we considered the deductibility of paid mortgage interest in the Dutch income tax system. Its origins were traced back to a basic tax rule that became outdated by the practical and political difficulties associated with taxing imputed rent and changes in the tax system itself. The main argument in favor of the deductibility of mortgage interest paid is that it stimulates homeownership, but the size of the subsidy and the fact that it is targeted towards the rich make this argument unconvincing to many. However, the large number of households making use of this facility is a major obstacle to abolishing it. In fact, the average mortgage payments of Dutch households have increased substantially in the past 25 years due to growing homeownership rates, increasing frequency of mortgage use, and changing mortgage type choices. Innovations on the mortgage market and the incentives for financing homeownership with mortgage loans provided by the current tax system were identified as important driving forces behind this development. Another important aspect is that the current Dutch tax system induces households - in particular elderly households that would otherwise have repaid the mortgage - to take more financial risks than they would otherwise do.

Even though the current Dutch government has declared that it does not want to reconsider the mortgage interest deductibility, it may be doubted if this tax facility will be sustainable in the long run. The deterioration of the income tax base that will result from further increases in the average amounts of mortgage interest paid will increase the pressure to limit or abolish the facility. As a matter of fact, some limitations on mortgage interest deductibility have already been introduced into the Dutch system. Since 2001 mortgage interest deductibility has been restricted to mortgage loans used to finance purchase, improvement, or maintenance of the house. Mortgage interest deductibility on second homes has been abolished, and the interest paid on a given loan can be deducted for at most 30 years. Since 2004 homeowners who move to another house first have to invest the equity accumulated in their old house in the new one. Only the mortgage interest paid for a loan that is used to finance the remainder of the price of the new house can be subtracted from taxable income.

It is conceivable that additional limitations on mortgage interest deductibility will be introduced in the coming years. If this happens, mortgage interest deductibility may gradually be reduced in a series of small steps. This would follow the example of the United Kingdom, where this tax facility was abolished incrementally over two decades. It must, however, be expected that subsequent reductions in mortgage interest deductibility will be increasingly more difficult to realize. The limited measures that have been taken thus far have been unable to reverse the strong upward trend in outstanding mortgage debt. It seems a priori improbable that further small limitations will be able to do so.

A more probable scenario is that pressure to limit this tax facility would suddenly become very strong after a substantial increase in interest rates that will probably coincide with a recession. In such circumstances budgetary pressures may force the government to take firm measures. In fact, the Netherlands has a tradition of postponing unpopular butin the long run-unavoidable measures until the economy deteriorates and the harsh measures needed to turn the tide become acceptable. This happened with social security reforms in the early 1980s and 1990s. It is not unlikely that mortgage interest deductibility 
will be maintained until such circumstances arise again. This would probably imply a bad timing of this measure. Indeed, house prices are vulnerable during a recession, and decreasing house prices may hamper economic recovery, as the experience in Sweden has shown. Though the first scenario is far preferable to the second one, unfortunately that does not make it more probable.

Acknowledgement The author thanks the editors and three referees for their constructive comments.

\section{References}

Boelhouwer, P., Haffner, M., Neuteboom, P., \& de Vries, P. (2004). House prices and income tax in the Netherlands: An international perspective. Housing Studies, 19, 415-432.

De Vries, P., Jansen, S., Lamain C., Boelhouwer P., \& Coolen H. (2006). Marktprijs en WOZ-waarde (Market Price and WOZ-Value, in Dutch). Report, OTB, Delft.

van Ewijk, C., Koning, M., Lever, M., \& de Mooij, R. (2006). Economische effecten van aanpassing fiscale behandeling eigen woning (Economic effects of adjustment of the fiscal treatment of homeownership, in Dutch). The Hague: CPB.

Glaeser, E. L., \& Shapiro, J. M. (2002). The benefits of the home mortgage interest deduction. Cambridge (Ma): Working paper, Harvard University.

Haffner, M. E. A. (2002). Dutch personal income tax reform 2001: An exceptional position for owneroccupied housing. Housing Studies, 17, 521-534.

Hendershott, P. H., Pryce, G. (2006). The sensitivity of homeowner leverage to the deductibility of home mortgage interest. Journal of Urban Economics, 60, 50-68.

Koning, M., Nistal, R. S., \& Ebregt, J. (2006). Woningmarkteffecten van aanpassing fiscale behandeling eigen woning (Housing market effects of adjustment of the fiscal treatment of homeownership, in Dutch). The Hague: CPB.

Renes, G., Thissen M., \& Segeren A. (2006). Betaalbaarheid van koopwoningen en het ruimtelijk beleid. (Affordability of housing and spatial policy). Rotterdam/The Hague: NAi/RPB.

van Rooij, M. J. C., \& Stokman A. C. J. (2000). Verzilvering overwaarde huis: Een statistische analyse van besteding en Risico's. (Cashing equity: A statistical analysis, in Dutch). Working paper, DNB, Amsterdam.

Vermeulen, W., \& Rouwendal, J. (2007). The price (In)elasticity of Dutch housing supply. Amsterdam: Working paper 07-058/3, Tinbergen Institute.

VROM (2006). Cijfers over Wonen 2006 (Figures about housing 2006). The Hague: Ministry of VROM.

Woodward, S. E., \& Weicher, J. C. (1989). Goring the wrong Ox: A defense of the mortgage interest deduction. National Tax Journal, 42, 301-313. 